\title{
PENGARUH “DRIVE HEAD" TERHADAP EFISIENSI DAN KEMAMPUAN “DELIVERY HEAD" MAKSIMUM PADA POMPA HIDRAM
}

\author{
Ahmad Rifandi ${ }^{1, *}$, Zayyin Kamil Billiman ${ }^{1}$ \\ ${ }^{1}$ Jurusan Teknik Kimia, Politeknik Negeri Bandung \\ Jln. Gegerkalong Hilir, Ds. Ciwaruga, Bandung 40012 \\ *E-mail: ahmad.rifandi@polban.ac.id
}

\begin{abstract}
ABSTRAK
Tujuan dari penelitian ini adalah untuk mempelajari pengaruh ketinggian sumber air (drive head) terhadap efisiensi dan kemampuan maksimum memompa air (delivery head) pada pompa jenis hidram. Pompa hidram yang dibuat terdiri dari ukuran $1 / 2,3 / 4$, dan 1 in. Dalam penelitian ini, air dialirkan dari tangki penampung sebagai sumber air melalui "drive pipe", selanjutnya pompa hidram memompakan air tersebut ke tempat yang lebih tinggi melalui "delivery pipe". Hasil penelitian menunjukkan bahwa tinggi sumber air umpan (drive head) dan tinggi tangki air penampung (delivery head) berpengaruh terhadap efisiensi pompa. Semakin besar drive head (h) dan delivery head $(\mathrm{H})$, untuk semua ukuran pompa, efisiensi pompa semakin menurun. Efisiensi tertinggi pompa yaitu pada pompa hidram ukuran 1 in dimana drive head $(\mathrm{h})$ pompa tersebut setinggi $0,55 \mathrm{~m}$ dan delivery head $(\mathrm{H})$ setinggi $3 \mathrm{~m}$ dengan efisiensi sebesar 56,73\%. Tinggi sumber air umpan (drive head) berpengaruh terhadap delivery head maksimum $\left(\mathrm{H}_{\max }\right)$, semakin besar drive head $(\mathrm{h})$ semakin besar delivery head maksimumnya $\left(\mathrm{H}_{\max }\right)$.
\end{abstract}

Kata kunci: Delivery head, drive head, efek water hammer, efisiensi, pompa hidram

\begin{abstract}
The purpose of this research is to study the influence of the height of the water source (drive head) on the efficiency and maximum height of water delivered (delivery head) of the hydraulic ram pump. The size of hydram pumps made in this research are $1 / 2,3 / 4$, and $1 \mathrm{in}$. Water is flowed from the storage tank as a source of water through a drive pipe, then the hydram pump pumps the water to a higher place through a delivery pipe. The results showed that the height of the feed water source (drive head) and the height of the discharge water tank (delivery head) affect the efficiency of the pump. The greater the drive head (h) and the delivery head (H), the pump efficiency decreases. The highest efficiency of the pump was reached at $56.73 \%$, where the size of the hydram pump is $1 \mathrm{in}$, and pump head (h) is as high as $0.55 \mathrm{~m}$ and the delivery head $(\mathrm{H})$ as high as $3 \mathrm{~m}$. The height of the drive head affects the maximum of the delivery head $\left(\mathrm{H}_{\max }\right)$, the greater the drive head $(\mathrm{h})$, the greater the maximum delivery head $\left(\mathrm{H}_{\max }\right)$.
\end{abstract}

Keywords: Delivery head, drive head, water hammer effect, efficiency, hydraulic ram pump

\section{PENDAHULUAN}

Perkampungan penduduk pada umumnya terletak di sekitar sumber air, baik itu berupa sungai maupun sumber mata air alami di sebagian besar wilayah Indonesia. Air untuk keperluan seharihari rumah tangga umumnya dimanfaatkan oleh penduduk dengan cara sederhana yaitu menggunakan air yang mengalir secara gravitasi. Adapun pada sebagian perkampungan yang dialiri listrik, penduduk memanfaatkan air tanah melalui pembuatan sumur yang dialirkan dengan menggunakan pompa listrik melawan tenaga gravitasi.

Tanah pertanian seperti sawah yang berada pada posisi lebih rendah dari aliran sungai biasanya memanfaatkan air dari aliran sungai untuk pengairannya, sedangkan tanah pertanian yang berada pada posisi di atas aliran sungai umumnya memanfaatkan air hujan sehingga digarap hanya selama musim hujan. Kondisi tersebut tentu merugikan bagi tanah pertanian yang masih terdapat aliran sungai disekitarnya namun 
posisinya di bawah tanah pertanian. Pemanfaatan pompa hidram (hydraulic ram pump) untuk untuk mengalirkan air sungai diharapkan menjadi solusi agar tanah pertanian tersebut selalu dapat digarap sekalipun tanpa musim hujan. Pompa hidram ini merupakan pompa yang ramah lingkungan, tidak menggunakan bahan bakar atau energi listrik untuk memompakan air ke tempat yang lebih tinggi.

\section{Efek Water Hammer}

Efek water hammer merupakan peristiwa meningkatnya tekanan air dalam waktu yang singkat pada suatu pipa (Browne, 2009). Ketika energi kinetik yang membantu pergerakan air berhenti secara tiba tiba maka akan terjadi efek water hammer yang mengakibatkan tekanan meningkat dengan cepat serta mengakibatkan terjadinya deformasi elastik pada cairan dan dinding pipa (Zuniga, 2018). Ilustrasi efek water hammer ditunjukkan pada Gambar 1.
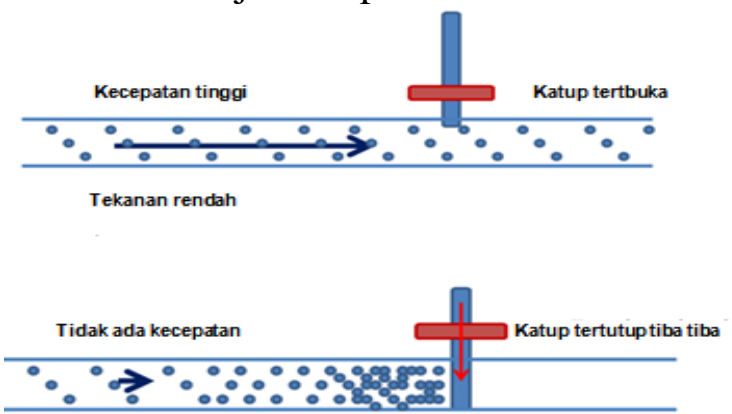

Gambar 1. Ilustrasi Efek Water Hammer Aliran Cairan dalam Pipa

Cairan yang mengalir dengan kecepatan tinggi dalam pipa memiliki energi kinetik. Jika katup yang menghalangi aliran cairan tersebut ditutup secara tiba-tiba, maka energi kinetik cairan tersebut akan diubah menjadi tekanan sehingga menimbulkan efek water hammer yang ditandai dengan suara keras seperti bunyi palu yang membentur logam.

\section{Pompa Hidram}

Pompa hidram bekerja dengan memanfaatkan tekanan cairan yang disebabkan oleh efek "water hammer". Apabila aliran cairan dalam pipa yang mempunyai inersia (momentum) ditutup perlahan dengan katup maka inersia tersebut yang berfungsi menahan agar kecepatan cairan tidak berubah secara tiba-tiba, akan hilang beberapa saat kemudian dan mengakibatkan tekanan cairan dalam pipa sedikit meningkat secara perlahan. Adapun jika katup yang menghalangi aliran cairan ditutup dengan sangat cepat maka gelombang kejut yang arahnya berlawanan dengan arah aliran semula akan muncul. Gelombang kejut yang dihasilkan akan semakin besar seiring dengan semakin cepatnya katup ditutup, serta seiring dengan aliran air yang semakin cepat karena dikarenakan inersia yang terlibat lebih banyak. Selain itu, gelombang kejut yang lebih besar juga akan dihasilkan oleh pipa yang lebih panjang dikarenakan alasan yang sama (Browne, 2009). Pompa hidram bekerja ketika air yang mengalir menghantam katup buang yang menyebabkan terhentinya aliran air secara tiba-tiba sehingga menimbulkan efek water hammer sebagaimana yang ditunjukkan pada Gambar 2.

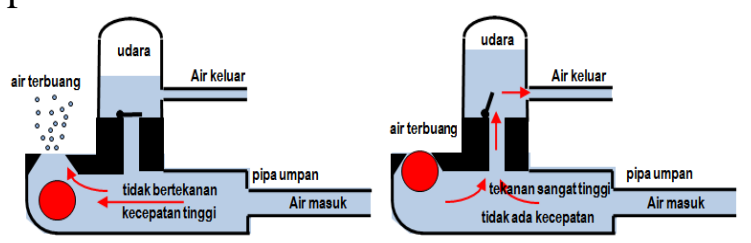

Gambar 2. Penggunaan efek water hammer pada pompa hidram

Efek water hammer yang timbul akan menyebabkan katup searah (delivery valve) terbuka sehingga air yang memiliki tekanan sangat tinggi akan masuk ke ruang air keluar yang berisi udara serta mengalir melalui pipa keluar (water delivery pipe) menuju tempat penampungan akhir. Air yang berada di ruangan ini tidak dapat kembali ke ruang pompa disebabkan adanya katup searah. Adapun tekanan di ruang pompa dalam 
keadaan normal kembali dan katup buang juga kembali terbuka. Aliran terbuka menyebabkan air mengalir kembali dengan cepat dan menutup katup buang yang kemudian menimbulkan efek water hammer. Pompa hidram hanya mengangkut air sebesar $20-40 \%$ dari aliran air yang masuk ke dalam pompa yang berasal dari sumber air penampungan. Menurut Browne (2009), pompa hidram bekerja mengubah tekanan akibat efek water hammer menjadi energi potensial untuk mengalirkan air ke daerah yang lebih tinggi. Efisiensi pompa hidram berkisar antara 50-80\% tergantung mutu bahan, desain dan usia dari komponennya.

\section{Efisiensi Kerja Pompa Hidram.}

Efisiensi pompa hidram pada umumnya dipengaruhi oleh pemasangan pompa itu sendiri, secara spesifik dipengaruhi oleh drive head ( $h$ ) dan delivery head $(H)$ (Zuniga, 2018).

Tabel hubungan antara efisiensi pompa terhadap ketinggian disajikan pada Tabel 1.

Tabel 1. Hubungan Efisiensi Pompa Hydram terhadap Ketinggian (Zuniga, 2018)

\begin{tabular}{|c|ccccccc|}
\hline $\mathbf{H} / \mathbf{h}$ & $\mathbf{2}$ & $\mathbf{3}$ & $\mathbf{4}$ & $\mathbf{6}$ & $\mathbf{8}$ & $\mathbf{1 0}$ & $\mathbf{1 2}$ \\
\hline $\boldsymbol{\varepsilon}$ & 0,85 & 0,81 & 0,76 & 0,67 & 0,57 & 0,43 & 0,23 \\
\hline
\end{tabular}

Efisiensi pompa hidram dihitung menggunakan persamaan berikut:

Di mana,

$$
q=\varepsilon \cdot \mathrm{Q} \cdot \frac{h}{H}
$$

$q$ = laju alir air hasil pemompaan atau delivery flow rate $(1 / \mathrm{s})$

$\varepsilon=$ efisiensi

$\mathrm{Q}=$ laju alir umpan atau drive flow rate $(1 / \mathrm{s})$

$h=$ ketinggian sumber air atau drive head $(\mathrm{m})$

$H=$ ketinggian pemompaan delivery head $(\mathrm{m})$

\section{Peningkatan Head Teoritis pada Pompa Hidram.}

Pompa hidram memanfaatkan fenomena berhentinya aliran dalam pipa secara tiba-tiba, yang kemudian menghasilkan tekanan tinggi. Jika aliran dalam pipa inelastic dihentikan secara tiba-tiba, maka kenaikan tekanan secara teoritis dapat diperoleh melalui persamaan berikut:

$$
\Delta H=V \frac{C}{g} \ldots \ldots \ldots(2)
$$

Di mana,

$$
\begin{aligned}
& \Delta H=\text { peningkatan tekanan / head }(\mathrm{m}) \\
& V=\text { kecepatan fluida dalam pipa }(\mathrm{m} / \mathrm{s}) \\
& C=\text { acoustic wave speed dalam fluida }(\mathrm{m} / \mathrm{s}) \\
& g=\text { gaya gravitasi }\left(\mathrm{m} / \mathrm{s}^{2}\right)
\end{aligned}
$$

Kecepatan gelombang akustik dalam sebuah fluida memenuhi persamaan berikut (Godavari Sugar Mills Ltd., 2007):

$$
C=\frac{E_{v}}{\rho}
$$

Di mana, $E v$ adalah modulus elastisitas yang menyatakan kompresibilitas sebuah fluida. Untuk air, nilai sifat $E v$ adalah $2.07 \times 10^{9} \mathrm{~N} / \mathrm{m}^{2}$. Selanjutnya kecepatan gelombang tekanan pada air adalah $\mathrm{C}=$ $1440 \mathrm{~m} / \mathrm{s}$, dan $\boldsymbol{\rho}$ merupakan massa jenis fluida $\left(\mathrm{kg} / \mathrm{m}^{3}\right)$.

\section{Pertimbangan praktis pada Desain Sistem Pompa Hydraulic Ram}

Berdasarkan Godavari Sugar Mills (2007), desain sistem pompa hidram harus mempertimbangkan faktor-faktor dibawah ini:

\section{Panjang pipa umpan (drive pipe)}

Panjang pipa umpan adalah komponen penting dalam instalasi pompa hidram. Pipa umpan harus mampu menjaga tekanan tetap tinggi pada saat menutupnya katup buang (waste valve). Hubungan empiris untuk menentukan panjang pipa ditentukan sebagai berikut:

$$
6 \mathrm{H}<\mathrm{L}<12 \mathrm{H} \text { (Europe \& North }
$$
America)

$$
\mathrm{L}=\mathrm{h}+0.3(\mathrm{~h} / \mathrm{H})(\text { Eytelwein })
$$

\section{$\underline{\text { Ruang udara (air chamber) }}$}

Volume air chamber yang direkomendasikan mendekati 100 kali volume air yang dipompakan setiap siklusnya. 


\section{Katup buang (waste valve)}

Luas pemukaan $\left(\mathrm{A}_{\mathrm{o}}\right)$ yang melalui waste valve harus sama atau lebih besar dari luas permukaan melintang drive pipe sehingga mencegah "chocking" pada aliran.

Katup pengeluaran (delivery check valve)

Luas yang direkomendasikan adalah 1,45 $\mathrm{cm}^{2}$ untuk setiap liter air yang dipompakan melalui delivery heck valve.

\section{Tinggi air umpan (supply head)}

Untuk katup pemompaan (delivery valve) yang beratnya sederhana, supply head (h) tidak boleh lebih dari $4 \mathrm{~m}$, jika lebih tinggi maka katup akan menutup dengan cepat dan sering. Untuk mengatur mekanisme penutupannya dalam kasus seperti ini, maka katup perlu dibantu oleh pegas.

\section{METODE}

Dalam penelitian ini digunakan rangkaian alat pompa hidram yang merupakan simulasi dari kondisi lapangan seperti yang ditunjukkan pada Gambar 3.

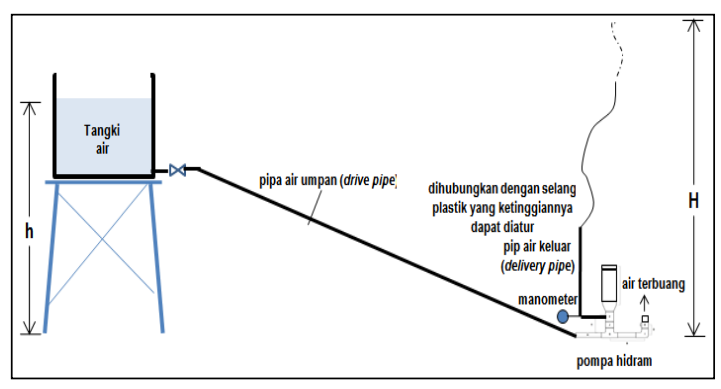

Gambar 3. Rangkaian Pompa Hidram

Dimensi dan komponen alat pompa hidram dalam penelitian ini dijelaskan pada Gambar 4 dan Tabel 2.

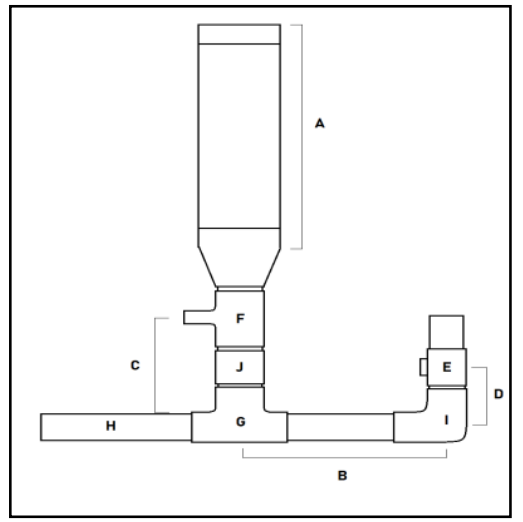

Gambar 4. Desain Pompa Hidram

Notasi:

$\mathrm{A}=$ Air Chamber

B = Panjang antara titik tengah Tee Connector dengan Elbow $90^{\circ}$

$\mathrm{C}=$ Tinggi keluaran pompa (delivery nipple) dari dasar pompa

$\mathrm{D}=$ Tinggi titik tengah Waste valve dari Elbow $90^{\circ}$

$\mathrm{E}=$ Waste valve berjenis Swing Check valve

$\mathrm{F}=$ Tee Reducer Connector

$\mathrm{G}=$ Tee Connector

$\mathrm{H}=$ Pump Pipe Inlet

Pada penelitian ini fluida yang digunakan adalah air. Tujuan dari penelitian yang dilakukan antara lain menentukan efisiensi pompa untuk masing-masing ukuran pompa dengan variasi ketinggian sumber air dari posisi pompa (drive head), yaitu $0,55 \mathrm{~m}, 0,96 \mathrm{~m}, 1,56 \mathrm{~m}$ dan $2,1 \mathrm{~m}$ serta ketinggian tangki penampung dari posisi pompa (delivery head), yaitu $3 \mathrm{~m}$, 3,8 m, 4,7 m dan 5,41 m.

Tabel 2. Dimensi dan Komponen Pompa Hidram

\begin{tabular}{|c|c|c|c|c|c|}
\hline Pompa & $\mathbf{A}$ & $\mathbf{B}$ & $\mathbf{C}$ & D & $\mathbf{E}$ \\
\hline $1 / 2 "$ & $43 \mathrm{~cm}$ & $\begin{array}{c}12,3 \\
\mathrm{~cm}\end{array}$ & $\begin{array}{l}20 \\
\mathrm{~cm}\end{array}$ & $\begin{array}{c}11,5 \\
\mathrm{~cm}\end{array}$ & $\begin{array}{c}\text { Swing } \\
\text { Check } \\
\text { valve } 1 / 2 " \\
\text { "Dcota" }\end{array}$ \\
\hline $3 / 4 "$ & $43 \mathrm{~cm}$ & $\begin{array}{c}12,3 \\
\mathrm{~cm}\end{array}$ & $\begin{array}{l}20 \\
\mathrm{~cm}\end{array}$ & $\begin{array}{c}11,5 \\
\mathrm{~cm}\end{array}$ & $\begin{array}{c}\text { Swing } \\
\text { Check } \\
\text { valve } 3 / 4 " \\
\text { "Dcota" }\end{array}$ \\
\hline $1^{\prime \prime}$ & $43 \mathrm{~cm}$ & $\begin{array}{c}12,3 \\
\mathrm{~cm}\end{array}$ & $\begin{array}{l}20 \\
\mathrm{~cm}\end{array}$ & $\begin{array}{c}11,5 \\
\mathrm{~cm}\end{array}$ & $\begin{array}{c}\text { Swing } \\
\text { Check } \\
\text { valve 1" } \\
\text { "Dcota" }\end{array}$ \\
\hline
\end{tabular}




\begin{tabular}{|c|c|c|c|c|c|}
\hline Pompa & $\mathbf{F}$ & $\bar{G}$ & $\mathbf{H}$ & I & $\mathbf{J}$ \\
\hline $1 / 2 "$ & $\begin{array}{c}\text { Tee } \\
\text { Connec } \\
\text { tor } 1 / 2 "\end{array}$ & $\begin{array}{c}\text { Tee } \\
\text { Connect } \\
\text { or 1/2" }\end{array}$ & $\begin{array}{c}1 / 2 " \\
\text { PV } \\
\text { C } \\
\text { Pipe }\end{array}$ & $\begin{array}{c}1 / 2 " \\
\text { PVC } \\
\text { Elbo } \\
\text { w } 90^{\circ}\end{array}$ & $\begin{array}{c}\text { 1/2" } \\
\text { Plastic } \\
\text { Springle } \\
\text { ss Check } \\
\text { valve }\end{array}$ \\
\hline $3 / 4 "$ & $\begin{array}{l}\text { Tee } \\
\text { Connec } \\
\text { tor } \\
3 / 4 " \text { to } \\
1 / 2 "\end{array}$ & $\begin{array}{c}\text { Tee } \\
\text { Connect } \\
\text { or } 3 / 4 "\end{array}$ & $\begin{array}{c}3 / 4 " \\
\text { PV } \\
\text { C } \\
\text { Pipe }\end{array}$ & $\begin{array}{c}3 / 4^{\prime \prime} \\
\text { PVC } \\
\text { Elbo } \\
\text { w } 90^{\circ}\end{array}$ & $\begin{array}{c}3 / 4 " \\
\text { Plastic } \\
\text { Springle } \\
\text { ss Check } \\
\text { valve }\end{array}$ \\
\hline $1 "$ & $\begin{array}{c}\text { Tee } \\
\text { Connec } \\
\text { tor } 1 " \\
\text { to } 1 / 2 "\end{array}$ & $\begin{array}{l}\text { Tee } \\
\text { Connect } \\
\text { or 1" }\end{array}$ & $\begin{array}{c}1 ” \\
\text { PV } \\
\text { C } \\
\text { Pipe }\end{array}$ & $\begin{array}{c}1 " \\
\text { PVC } \\
\text { Elbo } \\
\text { w } 90^{\circ}\end{array}$ & $\begin{array}{c}1 " \\
\text { Plastic } \\
\text { Springle } \\
\text { ss Check } \\
\text { valve }\end{array}$ \\
\hline
\end{tabular}

Penelitian ini juga menentukan ketinggian pemompaan (delivery head) maksimum untuk masing-masing ukuran pompa pada ketinggian tangki sumber air (drive head) 0,55 m, 0,96 m, 1,56 $\mathrm{m}$ dan $2,1 \mathrm{~m}$. Dalam penelitian ini pipa yang digunakan untuk menghubungkan tangki penampung air dengan pompa hidram (drive pipe) adalah pipa PVC berdiameter 1 inch dengan panjang 4,3 m, sedangkan untuk menghubungkan pompa hidram dengan tangki penampung (delivery pipe) digunakan selang plastik dengan diameter $3 / 8$ in dan panjang $8 \mathrm{~m}$, dimana ketinggiannya dapat diatur sesuai dengan ketinggian tangki penampung.

Untuk menentukan ketinggian pemompaan maksimum $\left(\mathrm{H}_{\max }\right)$ pada masing-masing pompa dengan ketinggian sumber air yang berbeda digunakan pressure gauge sebagai alat ukur delivery head maksimumnya. $\mathrm{H}_{\max }$ diukur pada saat pompa tidak dapat mengalirkan air $(\mathrm{q}=0)$.

\section{HASIL DAN PEMBAHASAN}

Pengaruh Ketinggian Sumber Air (Drive Head) dan Keluaran Air (Delivery Head) terhadap Efisiensi

\section{Pompa.}

Pada penelitian ini, pompa hidram yang dibuat terdiri atas pompa hidram ukuran 1/2,3/4, dan 1 in. Hasil penelitian pengaruh drive head dan delivery head terhadap efisiensi pompa untuk masing masing ukuran pompa adalah sebagai berikut.

\section{Pompa Hidram $1 / 2$ in.}

Hasil penelitian hubungan antara drive head $(\mathrm{h})$, delivery head $(\mathrm{H})$ dan efisiensi pompa untuk pompa dengan ukuran diameter $1 / 2$ in ditunjukkan pada Gambar 5 dan Tabel 3.

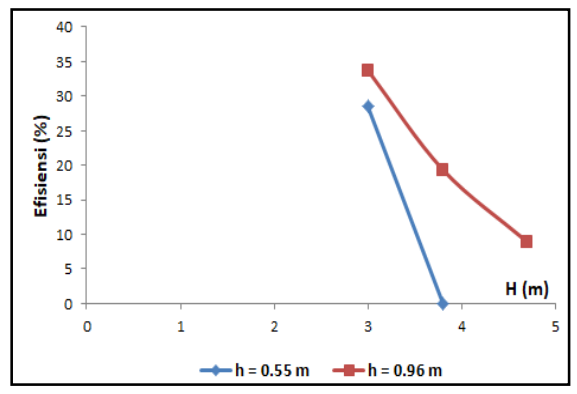

Gambar 5. Karakteristik Pompa Hidram $1 / 2$ in

Tabel 3. Pengaruh h dan $\mathbf{H}$ terhadap Efisiensi untuk Pompa Hidram $1 / 2$ in

\begin{tabular}{ccccccc}
\hline $\begin{array}{c}\mathbf{h} \\
(\mathbf{m})\end{array}$ & $\begin{array}{c}\mathbf{H} \\
(\mathbf{m})\end{array}$ & $\begin{array}{c}\mathbf{Q} \\
(\mathbf{L} / \mathbf{s})\end{array}$ & $\begin{array}{c}\mathbf{q} \\
(\mathbf{L} / \mathbf{s})\end{array}$ & $\mathbf{H} / \mathbf{h}$ & $\mathbf{q} / \mathbf{Q}$ & $\begin{array}{c}\boldsymbol{\varepsilon} \\
(\boldsymbol{\%})\end{array}$ \\
\hline $\mathbf{0 , 5}$ & 3 & 0,04 & 0,00 & 5,45 & 0,05 & 28,4 \\
$\mathbf{5}$ & & 2 & 2 & 5 & 2 & 4 \\
& 3,8 & 0,03 & 0,00 & 6,90 & 0,00 & 0,00 \\
& & 9 & 0 & 9 & 0 & \\
& 4,7 & - & - & 8,54 & - & - \\
& & & & 5 & & \\
& 5,4 & - & - & 9,83 & - & - \\
& 1 & & & 6 & & \\
$\mathbf{0 , 9}$ & 3 & 0,05 & 0,00 & 3,12 & 0,10 & 33,6 \\
$\mathbf{6}$ & & 4 & 6 & 5 & 8 & 9 \\
& 3,8 & 0,05 & 0,00 & 3,95 & 0,04 & 19,3 \\
& & 2 & 3 & 8 & 9 & 2 \\
& 4,7 & 0,05 & 0,00 & 4,89 & 0,01 & 8,90 \\
& & 5 & 1 & 6 & 8 & \\
& 5,4 & - & - & 5,63 & - & - \\
& 1 & & & 5 & & \\
\hline
\end{tabular}

Data yang diperoleh menunjukkan bahwa pompa hidram $1 / 2$ in memiliki kemampuan yang terbatas dalam menerima drive head (h) yaitu pada ketinggian $0,55 \mathrm{~m}$ dan $0,96 \mathrm{~m}$ karena pada drive head 1,56 $\mathrm{m}$ dan 2,1 $\mathrm{m}$ pompa hidram sudah tidak dapat berfungsi. Efisiensi pompa pada drive head (h) 0,55 
berkisar antara 28,44\%, sampai 0\%, dan pada $\mathrm{h}$ sebesar $0,96 \mathrm{~m}$, efisiensi pompa berkisar antara 33,69\%, sampai 8,90\%.

\section{Pompa Hidram $3 / 4$ in.}

Hubungan antara drive head (h), delivery head $(\mathrm{H})$ dan efisiensi pompa hidram ukuran diameter $3 / 4$ in ditunjukkan pada Tabel 4 dan Gambar 6.

Tabel 4. Pengaruh h dan $H$ terhadap Efisiensi untuk Pompa Hidram $3 / 4$ in

\begin{tabular}{|c|c|c|c|c|c|c|c|}
\hline $\begin{array}{c}\mathbf{h} \\
(\mathbf{m})\end{array}$ & $\begin{array}{c}\mathbf{H} \\
(\mathbf{m})\end{array}$ & $\begin{array}{c}\mathbf{Q} \\
(\mathrm{L} / \mathrm{s})\end{array}$ & $\begin{array}{c}\mathbf{Q}_{\text {cal }} \\
(\mathrm{L} / \mathrm{s})\end{array}$ & $\begin{array}{c}\mathbf{q} \\
(\mathrm{L} / \mathrm{s})\end{array}$ & $\mathbf{H} / \mathbf{h}$ & $q / Q$ & $\begin{array}{c}\varepsilon \\
(\%)\end{array}$ \\
\hline 0,5 & 3 & 0,08 & 0,08 & 0,00 & 5,45 & 0,09 & 50,4 \\
\hline \multirow[t]{7}{*}{5} & & 8 & 6 & 8 & 5 & 3 & 6 \\
\hline & 3,8 & 0,09 & 0,08 & 0,00 & 6,90 & 0,05 & 39,0 \\
\hline & & & 8 & 5 & 9 & 7 & 9 \\
\hline & 4,7 & 0,09 & 0,08 & 0,00 & 8,54 & 0,03 & 29,0 \\
\hline & & & 8 & 3 & 5 & 4 & 1 \\
\hline & 5,4 & 0,08 & 0,08 & $4 \times 10^{-}$ & 9,83 & 0,00 & 4,50 \\
\hline & 1 & 9 & 7 & & 6 & 5 & \\
\hline 0,9 & 3 & 0,1 & 0,09 & 0,01 & 3,12 & 0,15 & 47,2 \\
\hline \multirow[t]{7}{*}{6} & & & 8 & 5 & 5 & 1 & 2 \\
\hline & 3,8 & 0,10 & 0,09 & 0,01 & 3,95 & 0,09 & 38,8 \\
\hline & & 1 & 9 & 0 & 8 & 8 & 2 \\
\hline & 4,7 & 0,10 & 0,09 & 0,00 & 4,89 & 0,06 & 31,6 \\
\hline & & 1 & 9 & 6 & 6 & 5 & 8 \\
\hline & 5,4 & 0,10 & 0,10 & 0,00 & 5,63 & 0,05 & 29,6 \\
\hline & 1 & 3 & 1 & 5 & 5 & 3 & 2 \\
\hline 1,5 & 3 & 0,12 & 0,11 & 0,02 & 1,92 & 0,21 & 40,7 \\
\hline \multirow[t]{7}{*}{6} & & 1 & 8 & 5 & 3 & 2 & 3 \\
\hline & 3,8 & 0,12 & 0,12 & 0,02 & 2,43 & 0,16 & 39,9 \\
\hline & & 5 & 2 & 0 & 6 & 4 & 8 \\
\hline & 4,7 & 0,12 & 0,12 & 0,01 & 3,01 & 0,11 & 34,0 \\
\hline & & 7 & 4 & 4 & 3 & 3 & 8 \\
\hline & 5,4 & 0,12 & 0,12 & 0,00 & 3,46 & 0,07 & 25,0 \\
\hline & 1 & 8 & 5 & 9 & 8 & 2 & 2 \\
\hline \multirow[t]{8}{*}{2,1} & 3 & 0,12 & 0,12 & 0,04 & 1,42 & 0,33 & 48,1 \\
\hline & & 8 & 5 & 2 & 9 & 7 & 0 \\
\hline & 3,8 & 0,13 & 0,13 & 0,03 & 1,81 & 0,24 & 44,7 \\
\hline & & 7 & 3 & 3 & 0 & 7 & 8 \\
\hline & 4,7 & 0,13 & 0,13 & 0,02 & 2,23 & 0,20 & 44,6 \\
\hline & & 9 & 5 & 7 & 8 & 0 & 8 \\
\hline & 5,4 & 0,14 & 0,13 & 0,02 & 2,57 & 0,15 & 41,0 \\
\hline & 1 & 2 & 8 & 2 & 6 & 9 & 3 \\
\hline
\end{tabular}

Data yang diperoleh menunjukkan bahwa pompa hidram $3 / 4$ in memiliki kinerja terbaik pada drive head (h) $0,55 \mathrm{~m}$ dan delivery head $(\mathrm{H}) 3 \mathrm{~m}$ dengan efisiensi pompa sebesar 50,46\%.

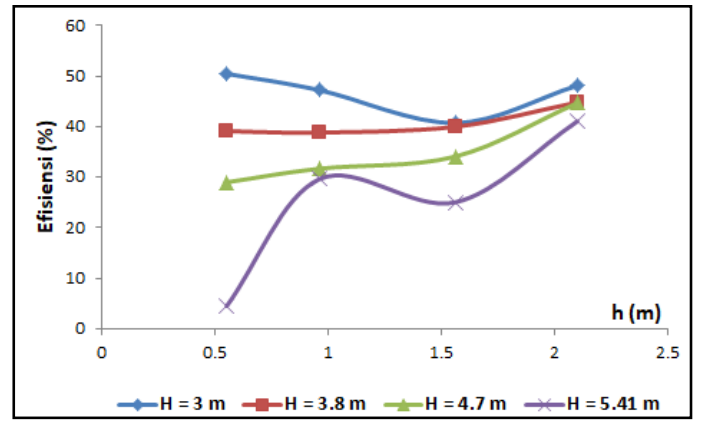

Gambar 6. Karakteristik Pompa Hidram $3 / 4$ in

Efisiensi pompa pada drive head (h) 0,55 berkisar antara $50,46 \%$, sampai $4,5 \%$, pada $\mathrm{h}$ sebesar $0,96 \mathrm{~m}$, efisiensi pompa berkisar antara $47,22 \%$, sampai $29,62 \%$, pada h sebesar $1,56 \mathrm{~m}$, efisiensi pompa berkisar antara 40,73\%, sampai $25,02 \%$, dan pada $\mathrm{h}$ sebesar $2,10 \mathrm{~m}$, efisiensi pompa berkisar antara 48,10\%, sampai 41,03\%. Pada drive head (h) sebesar 0,55 terdapat penurunan efisiensi yang cukup signifikan yaitu antara pemompaan pada $(\mathrm{H})$ sebesar 4,7 $\mathrm{m}$ dan $5,41 \mathrm{~m}$.

\section{Pompa Hidram 1 in.}

Hasil penelitian hubungan antara drive head $(\mathrm{h})$, delivery head $(\mathrm{H})$ dan efisiensi pompa hidram dengan ukuran diameter 1 in ditunjukkan pada Gambar 7 dan Tabel 5.

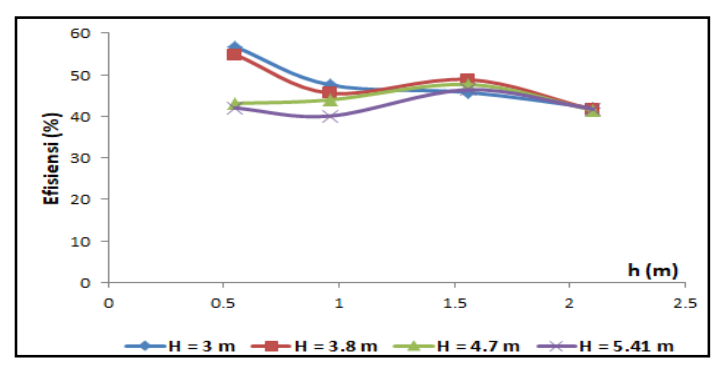

Gambar 7. Karakteristik Pompa Hidram 1 in 
Tabel 5. Pengaruh h dan $H$ terhadap Efisiensi untuk Pompa Hidram $3 / 4$ in

\begin{tabular}{|c|c|c|c|c|c|c|}
\hline $\begin{array}{c}\mathbf{h} \\
(\mathbf{m})\end{array}$ & $\begin{array}{c}\mathbf{H} \\
(\mathbf{m})\end{array}$ & $\begin{array}{c}\mathbf{Q} \\
(\mathbf{L} / \mathbf{s})\end{array}$ & $\begin{array}{c}\mathbf{q} \\
(\mathbf{L} / \mathbf{s})\end{array}$ & $\mathbf{H} / \mathbf{h}$ & $q / Q$ & $\begin{array}{c}\varepsilon \\
(\%)\end{array}$ \\
\hline \multirow[t]{4}{*}{0,55} & 3 & 0,125 & 0,013 & 5,455 & 0,104 & 56,73 \\
\hline & 3,8 & 0,126 & 0,010 & 6,909 & 0,079 & 54,83 \\
\hline & 4,7 & 0,119 & 0,006 & 8,545 & 0,050 & 43,09 \\
\hline & 5,41 & 0,136 & 0,006 & 9,836 & 0,043 & 42,01 \\
\hline \multirow[t]{4}{*}{0,96} & 3 & 0,138 & 0,021 & 3,125 & 0,152 & 47,55 \\
\hline & 3,8 & 0,139 & 0,016 & 3,958 & 0,115 & 45,56 \\
\hline & 4,7 & 0,137 & 0,012 & 4,896 & 0,090 & 43,96 \\
\hline & 5,41 & 0,124 & 0,009 & 5,635 & 0,071 & 40,06 \\
\hline \multirow[t]{4}{*}{1,56} & 3 & 0,151 & 0,036 & 1,923 & 0,238 & 45,76 \\
\hline & 3,8 & 0,150 & 0,030 & 2,436 & 0,201 & 48,85 \\
\hline & 4,7 & 0,158 & 0,025 & 3,013 & 0,158 & 47,67 \\
\hline & 5,41 & 0,157 & 0,021 & 3,468 & 0,134 & 46,39 \\
\hline \multirow[t]{4}{*}{2,1} & 3 & 0,17 & 0,05 & 1,429 & 0,294 & 42,02 \\
\hline & 3,8 & 0,174 & 0,04 & 1,810 & 0,230 & 41,60 \\
\hline & 4,7 & 0,178 & 0,033 & 2,238 & 0,185 & 41,49 \\
\hline & 5,41 & 0,179 & 0,029 & 2,576 & 0,162 & 41,74 \\
\hline
\end{tabular}

Data yang diperoleh menunjukkan bahwa pompa hidram 1 in memiliki kinerja terbaik dibandingkan dengan pompa hidram ukuran lainnya, yaitu pada drive head (h) 0,55 $\mathrm{m}$ dan delivery head (H) $3 \mathrm{~m}$ dengan efisiensi pompa sebesar $56,73 \%$.

Efisiensi pompa pada drive head 0,55 berkisar antara $56,73 \%$, sampai $42,01 \%$, pada drive head $0,96 \mathrm{~m}$, efisiensi pompa berkisar antara $47,55 \%$, sampai $40,06 \%$, pada drive head $1,56 \mathrm{~m}$, efisiensi pompa berkisar antara $45,76 \%$, sampai $46,39 \%$, dan pada drive head $2,10 \mathrm{~m}$, efisiensi pompa berkisar antara 42,02\%, sampai $41,74 \%$.

Pada pompa ukuran 1 in, efisiensinya relatif stabil, baik untuk drive head kecil maupun drive head besar, begitu pula untuk delivery head kecil dan delivery head besar. Pompa ini memiliki ukuran diameter pipa umpan (drive pipe) sama dengan ukuran diameter katup buang (waste valve). Hal ini sesuai dengan penelitian Zuniga (2018) bahwa efisiensi pompa mencapai kinerja tertinggi apabila ukuran diameter pipa umpan sama dengan diameter katup buang.

\section{Pengaruh Ketinggian Sumber Air (Drive Head) terhadap Keluaran Air (Delivery Head) Maksimum.}

Hasil penelitian pengaruh ketinggian drive head (h) terhadap delivery head maksimum $\left(\mathrm{H}_{\max }\right)$ untuk semua ukuran pompa hidram ditunjukkan pada Gambar 8.

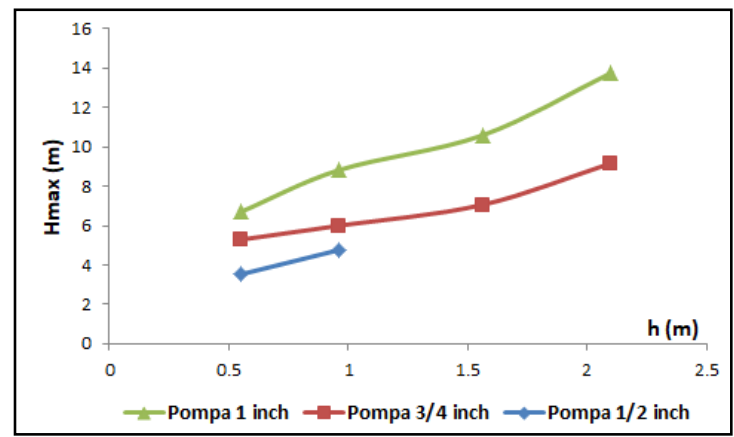

Gambar 8. Karakteristik Pompa Hidram 1 in

Pompa hidram $1 / 2$ in pada drive head (h) $0,55 \mathrm{~m}$ menghasilkan tekanan maksimum sebesar 5 psig atau $\mathrm{H}_{\max }$ sebesar 3,53 m, sedangkan pada drive head (h) 0,96 m menghasilkan tekanan maksimum sebesar 6,75 psig atau $\mathrm{H}_{\max }$ sebesar 4,76 m. Pompa hidram ukuran 1 in menghasilkan delivery head yang lebih besar dibandingkan pompa hidram $3 / 4$ in dan $1 / 2$ in karena air yang mengalir pada pompa hidram 1 in lebih banyak. Sebagai contoh, pada drive head (h) setinggi 0,96 $\mathrm{m}$ drive flow $(\mathrm{Q})$ pompa hidram 1 in sebesar $0,198 \mathrm{~L} / \mathrm{s}$ sementara pada pompa hidram $3 / 4$ in dan $1 / 2$ in masing-masing sebesar $0,128 \mathrm{~L} / \mathrm{s}$ dan $0,050 \mathrm{~L} / \mathrm{s}$. Pada ukuran diameter drive pipe yang sama, drive flow yang besar menghasilkan kecepatan aliran yang besar. Saat kecepatan yang besar tersebut membentur katup impuls (waste valve) yang tertutup maka benturan tersebut akan menghasilkan tekanan kejut yang besar (water hammer effect) sehingga tekanan air yang keluar dari pompa akan semakin besar. Selain itu, drive flow yang lebih besar akan menghasilkan nilai bilangan Reynold yang lebih besar sehingga 
berdampak pada semakin berkurangnya friksi pada drive pipe sehingga menyebabkan head losses semakin kecil.

\section{SIMPULAN}

Berdasarkan hasil penelitan yang telah dilakukan, dapat diambil kesimpulan bahwa tinggi sumber air umpan (drive head) dan tinggi tangki air penampung (delivery head) berpengaruh terhadap efisiensi pompa. Semakin besar drive head (h), untuk semua ukuran pompa, efisiensi pompa semakin menurun, begitu pula, semakin besar delivery head $(\mathrm{H})$ untuk semua ketinggian sumber air (drive head), efisiensi pompa semakin menurun. Efisiensi tertinggi pompa adalah sebesar $56,73 \%$, yaitu pada pompa hidram ukuran 1 in dimana drive head (h) pompa tersebut setinggi $0,55 \mathrm{~m}$ dan delivery head $(\mathrm{H})$ setinggi $3 \mathrm{~m}$. Tinggi sumber air umpan (drive head, $h$ ) berpengaruh terhadap delivery head maksimum $\left(\mathrm{H}_{\max }\right)$, yaitu semakin besar drive head (h) maka delivery head $(\mathrm{H})$ juga akan semakin besar. Ukuran katup waste valve yang sama dengan diameter pipa air umpan menghasilkan efisiensi pompa paling baik dibandingkan dengan ukuran katup waste valve yang lebih kecil dari diameter pipa air umpan.

\section{DAFTAR RUJUKAN}

Browne, D. 2008. Design, Sizing, Construction and Maintenance of Gravity - Fed System in Rural Areas - Modul 2: Principles and Sizing of a Gravity Fed System (online). https://www.pseau.org/outils/biblio/ resume.php?d=1670, diakses 7 Februari 2019.

Browne, D. 2009. Design, Sizing, Construction and Maintenance of Gravity - Fed System in Rural Areas - Modul 6: Hydraulic Ram Pump Systems (online). https://www.pseau.org/outils/biblio/ resume.php?d=2618\&l=en diakses 7
Februari 2019.

Godavari Sugar Mills Ltd. 2007. Hidram

Pumps (online). https://www.docdeveloppement-

durable.org/file/eau/pompes/belier-

hydraulique/hydram.pdf diakses 12 Februari 2019

Herlambang, A. \& Wahjono, H. D. 2006. Rancang Bangun Pompa Hidram Untuk Masyarakat Pedesaan. Pusat Teknologi Lingkungan, TPSA BPPT.

Smith, W. B. 2017. Home-Made Hydraulic Ram Pump for Livestock Water" (online). https://lgpress.clemson.edu/publicati on/homemade-hydraulic-ram-pumpfor-livestock-water/ diakses 8 Februari 2019.

Watt, S. B. 1981. A Manual on the Hydraulic Ram for Pumping Water. Nottingham: Intermediate Technology Publications Ltd.

Zuniga, P. M. A. 2018. Ram Pump Hydraulic Air Test Pressure Conditions and Flow Measurements. Gavle: University of Gavle, Faculty of Engineering and Sustainable Development. 